\title{
Keats and Fear of Death
}

\author{
MHD Noor Al-Abbood ${ }^{1}$ \\ ${ }^{1}$ Department of Foreign Languages, Taif University, Taif, Saudi Arabia \\ Correspondence: MHD Noor Al-Abbood, Department of Foreign Languages, Taif University, Al-Hawwiya, P. O. \\ Box 888, Taif 21974, Saudi Arabia. Tel: 966-55-856-7075. E-mail: noorabd@yahoo.co.uk
}

Received: March 1, 2015 Accepted: March 25, 2015 Online Published: May 31, 2015

doi:10.5539/ells.v5n2p103 URL: http://dx.doi.org/10.5539/ells.v5n2p103

\begin{abstract}
While emphasizing that the fears and conflicts expressed in "When I Have Fears" are in fact inseparable from the traumatic experiences Keats went through in his childhood and early adulthood, this article explains how they are experienced in the poem as conflicts with the transitory nature of time. Keats believes in his great potential but has fears that a premature death would not grant him the time to bring it to fruition. From this perspective, the article extends Samuel Cross's recent argument that Keats's Endymion displays poetic desires of "earliness" and "lateness" (Cross, 2011) to demonstrate similar desires operating in "When I Have Fears." For Keats, driven by an acute consciousness of time, forwards the temporal process of his poetic development to peer into the future he desires or wistfully lingers on those past or present vital moments curtailed by fleeting time. Furthermore, the article argues that the multivalent ending of the poem is of a piece with Keats's concept of negative capability in that it accepts the finality of death without resolving the conflict between life and death or sublimating his fears into some higher reality or an immortal afterlife. The article concludes by pointing out the irony that while the poem expresses Keats's fears that an early death would not give him the chance to achieve maturity as a poet, fear of death itself may be regarded as one of the driving forces behind his fast maturity and remarkable achievement. This astonishing achievement becomes all the more awe-inspiring in view of the brief life Keats was granted. Thus, rather than limiting his chance for fame, Keats's premature death has kept his memory alive and won him the fame he pined for.
\end{abstract}

Keywords: "When I Have Fears", earliness and lateness, fear of death, John Keats, negative capability, time

\section{When I Have Fears}

When I have fears that I may cease to be Before my pen has glean'd my teeming brain, Before high piled books, in charactery, Hold like rich garners the full ripen'd grain; When I behold, upon the night's starr'd face, Huge cloudy symbols of a high romance, And think that I may never live to trace Their shadows, with the magic hand of chance; And when I feel, fair creature of an hour, That I shall never look upon thee more,

Never have relish in the faery power Of unreflecting love; - then on the shore Of the wide world I stand alone, and think Till love and fame to nothingness do sink.

Although "When I Have Fears" was written in January 1818, before the death of Keats's brother Tom and before his own diagnosis of tuberculosis, the fear of a premature death and the concomitant anxiety about an aborted poetic career, which the poem expresses, can be understood by reference to his earlier traumatic experience of the constant passing away of his family members and relatives. For example, his father Thomas Keats died in 1804, at the age of 31, when he fell off his horse. John was then only eight and a half years old (Coote, 1995, p. 
7). Keats, who had then to take responsibility for his mother and his siblings as the eldest son of the family, found himself nursing his mother until she died in 1810 of tuberculosis, the disease that would prove to be indeed a family illness. Keats was devastated by the death of his mother and the ensuing shattering of the family. As William Walsh (1981) explains, "Keats was deeply attached to his mother. Her curious and hasty second marriage distressed him and her death that shattered the family circle scarred him permanently. He wanted to be close to his sister but this became more and more impossible because of the jealous guardianship of Abby... " (p. 53). In January 1818, at the time when he composed "When I Have Fears," "another agonizing period in Keats's life, of anxiety and fear, was starting," as his brother Tom began spitting blood and showing unmistakable signs of consumption. In Keats's times, Walsh reminds us, the diagnosis of tuberculosis provoked "horror and doom" because it suggested "fate, misery and terror" (p. 44). Tom's illness further exasperated Keats's devastation following the death of his mother and father. "Keats's life was harsh and sad," writes Walsh, and "[t]he grimness of life, experienced from the first in the tragic deaths of his father and mother, and the shattering of the family, was brought home to him again by the state of Tom's health." Later in his life, Keats would come to realize the effects of such tragic events on his life and happiness. "I have never known any unalloy'd Happiness for many days together," he complained to Fanny Brawne in July 1819, "the death or sickness of someone has always spoilt my hours" (2005, p. 309). Indeed, if Keats became later aware of "a horried Morbidity of Temperament" (2005, p. 23), his past traumatic experiences "would certainly justify it" (Walsh, 1981, p. 7).

These recurring tragic episodes of sickness and death, which punctuated Keats's brief life, certainly shed light on Keats's short-lived poetic career, showing the origins of the anxieties and fears expressed in "When I have Fears" as well as in much of his poetry. In fact, many biographers and critics of Keats have already broached this connection between Keats's private life and his poetic career, including Keats's obsession with the "dark" theme of death and the brevity of life. Referring to the fact that by the age of fifteen he was a complete orphan, Christopher Miller (2011) writes that Keats "was just as clear-eyed as Byron in his tragic sense of life" (p. 134). Similarly, Walsh (1981) argues that "[a]s a poet," Keats "was too possessed by the tragic view of man," for his life, "as a man" "was riven with too many tragedies" (p. 6). Douglas Bush (1963) goes so far as to suggest that Keats's best poems are those ones that dramatize his personal conflicts. "From first to last," Bush argues, "Keats's important poems are related to, or grow directly out of ... inner conflicts" (p. 82). More specifically, Tom's illness and death, and the anguish, fears and conflicts which they have caused in Keats in consequence, are often cited in connection with particular themes or specific works. For example, Andrew Motion (1997) finds that the conflict between love and death, which permeates "Bright Star," "The Eve of St. Agnes," and other poems written in 1818, is inseparable from Keats's conflicted feelings about such women as Jane Cox, Isabella Jones and Fanny Brawne at a time when he was tending his dying brother. He therefore draws attention to "the strong association between love and death which existed in Keats's mind as he nursed his brother" (p. 323). Walsh (1981) advances a similar argument, relating the fears and anxieties caused by Tom's illness to the way Keats envisages the conflict between life and death in Hyperion and the final odes:

Tom was sinking, and Keats was composing Hyperion. The pull of death against the attraction of life was a deep, constitutive tension in Keats's experience and his art. Hyperion, while it did not itself contain it, except perhaps in patches, helped towards the living equilibrium of the two he achieved finally in the great Odes. He did not succeed in arriving at anything as satisfying in his personal life (p. 55).

From a related perspective, Brendan Corcoran (2009) likewise insists that to understand Keats's "idea of death," one has to take into account "the actual presence of death in Keats's life and his study of death through and in the poetry" (p. 324). Although he declines the attempt to discern a specific or "originary biographical death-encounter that somehow triggered Keats's attentiveness to the subject" of death, Corcoran argues that Keats's "poetic life is reconstituted around an encounter with death, as in the Freudian notion of trauma" (p. 346) Noting Keats's representations of events or feelings from a "posthumous" vantage point (as in "This Living Hand," "Bright Star," "La Belle Dame sans Merci," and the last letters), Corcoran attempts to utilise the literary dimensions of trauma in Keats's poetry, which involves "the representation and apprehension of the human experience - or survival - of death." For Keats's works often show how he is trying to come to terms with a "deadly crisis," not merely by getting over it, but by living repeatedly and interminably its aftermath (p. 325). For example, the "knight at arms" survives his deathly encounter with La Belle Dame sans Merci, but the experience has left him traumatised forever. He is perpetually "Alone and palely loitering" in a barren land, recounting "posthumous" tales from the underworld of "pale kings," "princes" and "warriors" with "starv'd lips in the gloam" (11. 37-8, 41).

If the thrust of Corcoran's argument is that Keats's work involves a "posthumous poetics," Samuel Cross (2011), in his recent study of Keats's early work Endymion, makes the comparable point that Keats's work displays 
temporal anxieties as a consequence of his poetic desires of "earliness" and "lateness." Cross shows how Keats, driven by desire for maturing fast and becoming a major poet, talks about his present work from the perspective of the future when this work is finished and celebrated. However, the desire to land in the future also involves "overshooting" vital past or present states or moments, which Keats therefore wistfully wishes to go back to and re-live (p. 124).

Having emphasized above that the fears and conflicts expressed in "When I Have Fears" are in fact inseparable from the traumatic experiences Keats went through in his childhood and early adulthood, this article will show how they are experienced in the poem as conflicts with the transitory nature of time. Keats believes in his great potential but has fears that a premature death would not grant him the time to bring it to fruition. From this perspective, the article will extend Samuel Cross's argument that Keats's Endymion displays poetic desires of "earliness" and "lateness" to demonstrate similar desires operating in "When I Have Fears." For Keats, driven by an acute consciousness of time, forwards the temporal process of his poetic development to peer into the future he desires or wistfully lingers on those past or present vital moments curtailed by fleeting time. Furthermore, the article will show that the multivalent ending of the poem is of a piece with Keats's concept of negative capability in that it accepts the finality of death without resolving the conflict between life and death or sublimating his fears into some higher reality or an immortal afterlife.

While shedding light on Keats's whole oeuvre, the remarks Bush, Motion, Walsh, and Corcoran make with regard to the effects Keats's personal life left on his poetic career are particularly relevant in explaining how the traumatic experiences Keats went through in his childhood and early adulthood have given rise to the fears and conflict expressed in "When I Have Fears." A psychoanalytically based reading of the poem would certainly capitalize on these details to detect a tension between "the attraction of life" and "the pull of death" in the form of conflict between the desire to live and be productive and the fear of a premature death that will make such a desire untenable. Keats aspires to be an accomplished poet and wishes to enjoy fame and a fulfilling love life, but he has fears that an early death would destroy his chance. In fact, as the poem progresses, Keats's death anxiety deepens, taking on crisis proportions at the end, as he is driven to wonder if life has any meaning in the face of a looming death - what value and meaning do fame, ambition, and love have? Keats stands on the shore of the wide world, helpless watching his desires for love and fame sink into the dark ocean. His (love) life and career ambitions are mere victims of death, which seems to be beyond reason or control:

... then on the shore

Of the wide world I stand alone, and think

Till love and fame to nothingness do sink

Psychoanalysts believe that fear of death is essentially fear of the loss and non-fulfilment that death will bring about, which in turn generates other fears, such as fear of abandonment and even fear of life itself (Williams, 1958, p. 158; Williams, 1962, pp. 29-30; Tyson, 2006, p. 22). Interestingly, in "When I Have Fears," Keats is not expressing fear of biological death as such, but rather fear of unfulfilled poetic career and loss of love due to early death. He is afraid of dying without having accomplished the poetic deeds he both pines for and is capable of achieving if granted enough time. "Life must be undergone," Keats wrote to Benjamin Bailey in January of 1818 around the time he wrote "When I Have Fears," "and I certainly derive a consolation from the thought of writing one or two more Poems before it ceases" (2005, p. 129). Likewise here in the poem, Keats is not simply saying "When I have fears that I may cease to be," but "When I have fears that I may cease to be / Before my pen has glean'd my teeming brain" (my emphasis). Moreover, Keats's fear of death awakens in him not only fear of loss of the opportunity to fulfil his poetic ambitions, but also anxiety about loss of love and separation from "the creature of an hour." The "fair creature of an hour" refers to a beautiful woman Keats once glimpsed in Vauxhall Gardens in 1814. She seems to have left such a lasting impression on Keats that she remained ever after in his imagination as the paragon of perfection and beauty. Keats expresses the fear that a premature death would rob him of the chance to meet again and be with this woman. She is "glimpsed once, then lost for ever" (Roe, 2012, p. 210), as the brevity of life will make a second encounter impossible. This fear intensifies as the poem progresses towards the feared end, and turns into fear of abandonment as the poem literally ends, thus signaling the imagined end of the poet's life. This is apparent in the image of Keats standing alone on the shore of the wide world, which is a natural barrier between the land and the sea, as if abandoned by the very world in which he has grown up and still feels emotionally attached to. As Keats would later write from the ship taking him to his Italian exile and death, mourning his doomed love and life, "Land and Sea, weakness and decline are great seperators, but death is the great divorcer forever" (2005, p. 475).

However, as Keats is seized by fears of his love and life being terminated by an early death, he becomes painfully conscious of time. Thus, the tension between the attraction of life and the fear of death is transformed 
immediately into a conflict between the desire for life and the fleeting nature of time, which would therefore not allow the poet to enjoy life's pleasures and rewards such as love and fame. In this view, the poem registers the grievance of a poet who believes in his poetic potential but is painfully aware of the limited temporal space to bring it to maturity and fruition. In fact, Keats's awareness of fleeting time typically triggers in him the desire to annihilate temporality and transcend the limits of human mortality. For instance, in his sonnet to Reynolds (1818), he wishes "that a week could be an age,"

So could we live long life in little space;

So time itself would be annihilate. (1l.1, 5-6)

Observing the intense awareness of time that permeates Keats's poetry, Robert W. Stallman (1947) goes so far as to contend that "[ $\mathrm{t}] \mathrm{he}$ soul of a Keats poem is intelligible only by having regard to the poet's conception of time. Time is Keats's cardinal theme, figuring either as the total intention of his poems or as the obsessive motif of his minute particulars" (p. 143). Seizing upon Keats's expressed desire to "annihilate" time, Stallman goes on to argue that Keats's relationship to time is that of intense "opposition" and enmity, which can be detected "[e]verywhere in his poetry, not only in the later poems expressing his premonition of death, but equally in the earlier ones, like 'On Death' (1814) or 'When I Have Fears' (1818)." However, opposition to time is bound to be a losing battle since the poet cannot arrest time, let alone reverse its injurious effects. Citing Keats's remark on the impossibility that "a rose should shut, and be a bud again" ("The Eve of St Agnes," 1. 243), Stallman points out to the fact that Keats is sorely aware of "time's uniquely occurring onceness and irreversibility" (p. 143). Here in "When I Have Fears," this recognition of the claims of time - that time is inexorably and irreversibly forward moving - sparks off Keats's worries about his present achievement and future prospects, since "in the moment now lies the burden of the moment before and the moment after," as Stallman puts it (p. 143). Indeed, Stallman's choice of "burden" aptly suggests the pressure of time that Keats feels at the present, and his deep worries about a future he both impatiently pines for and exceedingly dreads. For the future holds hopes for him to achieve his potential but it equally threatens to thwart these very hopes with the possibility of a premature death. Robert Burns, the "[p]oor unfortunate fellow" (Keats, 2005, p. 150) whom Keats greatly admired and eulogized on more than one occasion (for example, the two 1818 sonnets "Written in the Cottage Where Burns Was Born" and "On Visiting the Tomb of Burns"), and whose illnesses and fate reminded Keats of his own mortality, perhaps sums up Keats's predicament in "To a Mouse" (1785):

But Och! I backward cast my e'e,

On prospects drear!

An' forward, tho' I canna see,

I guess an' fear! (11. 43-46)

Time-conflicts in Keats's work- his desire and anticipation, fears and anxieties-that arise from the contemplation of what Stallman calls as "the burden of the moment before and the moment after" are also detectedby Samuel Cross (2011) as symptoms of Keats's desire for "earliness" and "lateness." In his informative study of Keats's Endymion and "To Autumn," Cross likewise argues that the brief poetic career of Keats is marked by "temporal anxieties" (p. 117). The poems written in this short period, which began with Endymion in 1817 and ended with "To Autumn" in 1819, are imbued with a language of poetic desire that reflects Keats's feelings about "earliness" and "lateness" (p. 118). Both feelings and the desire they contain seem to be the product of believing that he has only a short time to mature and write the "verses fit to live" (Keats, 1982, p. 64). As Cross (2011) explains, Keats's wishful earliness involves the "desire to achieve a state not yet arrived at or heretofore only imperfectly attained; it is anticipatory because the state longed for is most unknown and envisioned." Concurrently, lateness involves "the desire either to return to a well-known and more vital state, or to arrive at a place that one has already somehow 'overshot,' or where one already is or has been in some merely partial sense" (p. 124). In other words, as a consequence of his excruciating worries about his present immaturity and future status, Keats often expresses the wish to annihilate time through desire (p. 124), to negate the present and leap forward into the imagined future (the desired maturity). In doing so, Keats ends up speaking about present or future "facts" from the perspective of a future point in time when these facts will be already accomplished (p. 123), as when he says in a letter of October 1817 that he will have "no Laurels till I shall have finished Endymion" (Keats, 2005, p. 42). In contrast to the desire of "earliness," lateness in Keats takes the form of a wish to be "more 'in' time, more naturally and normally susceptible to its usual pace or progress" (Cross, 2011, p. 125), especially with Keats's awareness in such instances that he has only partially enjoyed a former vital state or only partially lived through an overwhelming experience. 
As an example of Keats's sense of lateness, Cross cites Keats's letter of November 1820 where he makes the famous and most painful statement in his letters at all: "I have an habitual feeling of my real life having past, and that I am leading a posthumous existence" (2005, p. 485). Here Keats, totally emaciated and in full knowledge of his approaching death, feels that he has now left behind that full vibrant life he has longed for and thought he has almost reached, and that he is now merely a tortured spirit, an alienated ghost of the formerly living Keats. For having lost the ability to write, he is now not only separated from his former life because he is living beyond it, but also because he cannot communicate with that vital phase of his life by means of writing (Cross, 2011, p. 127). Cross contends that "To Fanny" and the late letters of Keats are permeated by a sense of longing for experiences that are now past him, or to make an end. In these final pieces, Keats seems at times so preoccupied with bitter feelings of lateness, because, dying and with no belief in an afterlife, he now realizes the helplessness and barrenness of lateness in comparison to earliness. For the hopes to return to an unrecoverable past moment are imaginatively much less fulfilling than the hopes to arrive at a future state one is almost sure of (p. 127).

If both the desire for earliness and the desire for lateness are equally a negation of normal temporal boundaries, each, however, focuses the poet's attention on a different space of experience or feeling - the one on the future and the other on the present and past. Yet both desires are "twinned" in the sense that the one gives rise to the other, both of them consequently occurring at the same time or in the same context (p. 118). As Cross shows us, this is demonstrable in Endymion because Keats uses "a language of transformative temporality in which the past is pulled wistfully forward into the present, and the future made anxiously near" (p. 118). Having demonstrated this tendency in Endymion, Cross goes on to argue that the same tendency becomes clearer in Keats's final works. In the late odes, Cross observes, Keats's temporal anxiety becomes more acute, as these odes display a kind of dialectic oscillation, wishing or dreaming "themselves in and out of various states, becoming themselves confused rather than confusing states within themselves," as when Keats asks himself at the end of "Ode to a Nightingale:" "Do I wake or sleep?" (p. 129). Only "To Autumn," particularly its last stanza, is singled out as an exception in Keats's typical language of desire. According to Cross, in "To Autumn" Keats is able to hold "in vibrant tension the potentialities of past and future" (p. 129), to put his temporal anxiety under control and use it in the service of simultaneously seeing and speaking different times (p. 118). Endymion is saturated and confused with images of earliness and lateness - images of spring and autumn are chaotically mingled (p. 120), the physical signs of the future appear astonishingly in the present, and the quickening spring becomes already autumnal (p. 121). However, though similarly rife with images of earliness and lateness, "To Autumn" ultimately favours and establishes stasis, allowing earliness and lateness, the longed-for or feared future (desired maturity or feared death) and the obvious past (life; the earlier warmth of spring, summer, and early autumn) to coexist adjacently in each line without preferring one to the other (pp. 127-9). As such, Cross concludes that the advancement of Keats's brief poetic career from Endymion to "To Autumn" is not a matter of "initiation and completion," as the majority of Keats's biographers and critics believe. It is rather "ambition and acceptance, or desire and desire's annulment" (p. 118). For it is desire which has made Keats annihilate the present and hasten the future, with the ensuing confusion of earliness and lateness. Therefore to choose stasis, to refuse to replace earliness with lateness or vice-versa, is to annul this desire, to give up the former ambition and veer toward acceptance (of the status quo, including the duality of life and death). In other words, Keats in "To Autumn" experiences a leap in poetic self-consciousness, as he becomes aware of, and comes to reject, the temptation to experience earliness and lateness, meanwhile understanding his own powers as well as proclivities as a poet. Cross nevertheless concedes that Keats had all along special "prospective and retrospective sensitivity" because "Keats, as a poet, felt and habitually expressed the transparency of past, present, and future to each other with great strength" (p. 129).

Extending Cross's argument in these terms, it is possible to demonstrate similar desires of earliness and lateness operating in "When I Have Fears." First, the sonnet testifies to Keats's extraordinary prospective and retrospective sensitivity, to how he feels and expresses the transparency of different temporalities and localities to each other. Anxious about the prospect of an early death, Keats leaves the present and leaps into the future when he is face to face with death, so to speak. It is from the perspective of the future (death) that he reports his feelings and imagination about the past, the present and the future. If he ceases to be in the near future, this means that he will not be able to fulfil his potential and become a great poet, nor will he be able to enjoy a possible love relationship. Further, it is due to the contemplation of this frightening futuristic scenario that his present longing for love and fame crumbles into nothingness.

The tension between earliness and lateness in the poem is tremendous. Fearing a brief life and a brief career, Keats unveils his desire to achieve a state not yet arrived at or heretofore only imperfectly attained. He feels that he is not yet a major poet but that he has all the potential to be one. His brain is now "teeming" with ideas and possible poems, and in time he will author innumerable books that will contain his mature thoughts and mature poetry: 
"high-piled books, in charactery, / [will] Hold like rich garners the full ripen'd grain." Many promising, albeit unclear yet, signs of future growth and development, those "Huge cloudy symbols of a high romance," Keats keenly observes now. However, only in the coming future will he be able to "... trace / Their shadows," and turn them into "a high romance." As for love, he had in the past only a brief encounter with it. Thus, emotional fulfilment, in the words of Cross, is either not arrived at yet or only imperfectly attained up till now. However, the future may hold the possibility of meeting that "fair creature of an hour" again. The feeling is therefore that of promise and anticipation of excitement, because a possible future emotional fulfilment is envisioned when Keats will "have relish in the faery power / Of unreflecting love."

If we take the first two stanzas as examples of earliness, it is not difficult to see how Keats speaks about imagined future facts as though accomplished from the perspective of the longed-for future. Indeed, Keats's transformative temporality does not only render the future fruitful but speaks, as Cross points out, from the perspective of fruitfulness itself (p. 123). Neither the "pile of books" nor "the full ripen'd grain" exists yet in the present. Nor for that matter the "high romance." As Cross argues with regard to Endymion, Keats's approach to temporality "tends to imagine that present tokens can bring futurity into the present, or at least can intimate it so strongly that it becomes visible" (p. 123). In this regard, the autumnal imagery in the first stanza is telling. Autumn is the fructifying season; the ripening grains and mellow fruits of autumn are not only already anticipated in the spring season but are also assured in autumn. The cyclic movement of the seasons is inexorable, and Keats seems to borrow seasonal imagery and power precisely in order to suggest his sure forthcoming maturity and the ensuing triumphs whose glimmers are now abundantly visible. As Cross points out, "Keats frames his own poetic career in terms of natural development: the present promises and stands (in) for the future" (p. 121). He talks of piles of books that he will, at a point of time in the future, have written - those books that will "Hold like rich garners the full ripen'd grain." He leaps into the future to tell us about the "high romance" that will have been written then, based on his present observation and inspiration of its elements. Similarly, from the perspective of the future, Keats will enjoy a fulfilling love relationship, as his past encounter of "an hour" will have blossomed into a full-fledged romance.

It is important, however, to take cognizance of Cross's argument with regard to the use of the structure of the seasons in Endymion. Cross argues that such a structure also gives Keats the language he "uses to register his poetic and personal anxiety about timeliness," for example the fear of not finishing Endymion on time or of being behind schedule (p. 117). Here in this poem, Keats similarly uses the same language to register his poetic and personal anxiety about an untimely death. The poem essentially expresses his fear that he may die before he has written all those poems whose intimations he sees now. In other words, if the language of poetic desiring, which Keats borrows from the structure of the seasons, appears in a sense to assuage his anxiety about his present immaturity by assuring himself of the sure forthcoming autumnal fruition of his poetic talent, such a language also, ironically, makes him all the more painfully aware of his present immaturity and all the more worried about dying before he has the time to mature and become a major poet (cf Cross, 2011, p. 123).

From a different perspective, despite Keats's desire for earliness, which we have observed above, here one can notice his overwhelming sense of lateness, too. As Cross points out, earliness is "twinned" with lateness in Keats, since the very desire for earliness turns out to be a fear of being late - too late, in fact. In other words, the desire to annihilate time and forward the natural process, imagining its end results at its outset, gives the impression that Keats has "discomfort with the present time" (127), that he is unhappy about how things are progressing now. Certainly, from the perspective of the feared prospect of a premature death, Keats would feel as though he is not maturing fast enough. He therefore cannot overcome death with the established status of a major English poet. This is in part what accounts for the rueful tone of the poem. Moreover, faced with the prospect of a premature death, Keats is especially aware that he has only partially lived through an exciting experience, such as falling in love with "the creature of an hour." The usual pace of time would give Keats a second chance at love and emotional fulfilment. Moreover, from the point of view of the late doomed future (death), Keats would wish to linger a while longer in the present to take in all those inspiring signs, shadows and glimmers, to grow better poetically and intellectually, to fulfil himself before the hour of death strikes. In other words, lateness is experienced here in the form of a wish to go back to an exciting former but incomplete experience or to undergo the normal pace of time without having to hasten and therefore miss emotionally gratifying or poetically enhancing experiences.

In the terms stated in Cross's argument, perhaps the bitterest sense of lateness in the poem is expressed in the final three lines. The image of Keats standing desolately at the edge of the world, losing himself in thoughts about the value of his career ambitions and longing for love, brings to mind his famous statement about living a posthumous existence, with his feeling of his real life having passed. To use a phrase from Cross's touching comment on Keats's exiled Italian existence awaiting certain death, Keats seems here and now at the end of the poem as "a kind 
of tortured spirit in an alien scene," feeling "he had lived out or lived beyond that portion of his life that had been really vital" (p. 127):

... then on the shore

Of the wide world I stand alone, and think

Till love and fame to nothingness do sink.

Indeed, from the perspective of his imagined future "posthumous" existence, the most important phase of his life is over now, and his poetic career and love life are behind him, as is suggested by the image of him leaving everything behind and standing alone on the shore of the wide world, watching his fortunes in love and fame fade away. In fact, the posthumous existence that the final lines suggest has already been anticipated by the previous lines, which project the perspective of the future - death. Moreover, the one-sentence structure of the sonnet, its syntax and rhyme scheme also pave the way for such a conclusion.

Interestingly, one can also observe here in the final three lines of the poem what Cross calls "ambition and acceptance, or desire and desire's annulment." In this regard, it is important to notice the wording of the last two lines. Keats imagines himself standing on the shore, thinking not about his vanishing fortunes in love and fame, but thinking "Till love and fame to nothingness do sink" (my emphasis). The choice of preposition in the final line is explained by the fact that "When I Have Fears" is "in the end ... a poem with a deadline, a poem aware of its own conclusion, its inevitable movement from presence to absence" (Chander, 2012, p. 215). Fearing to cease to be causes Keats to cease to desire. However, the termination of desire, which is accentuated by the word "till," is not the result of resolving the conflicts and tensions between desire for life and fear of death, which have given rise to the poem in the first place. It is just an acknowledgement of the depth and extensive power of Keats's anxiety. Keats's fears about his life ending in a premature death thwart his desire for love and fame, thus making him unable to enjoy fully his present life. In contrast to "To Autumn," the poet here ceases to desire not because he has become aware of his strength as a poet, or because he has domesticated his proclivities for desiring a speedy magical earliness or for using the language of lateness, but precisely because he is still preoccupied with feelings of earliness and lateness.

From a different perspective, the poem's movement from ambition to acceptance of fate, and from desire for fame and love to termination of this desire, without resolving or sublimating either the fears or the annulled desires into some higher reality or rewarding afterlife (cf Goldberg, 1957, p. 125), opens the ending of the poem to a possible reading from the perspective of Keats's own concept of "Negative Capability." Negative capability certainly explains Keats's quiet, almost stoic acceptance of the inevitability of death and the termination of his worldly desires. The basic principle of negative capability is to possess the capability to take in the world, with its good and evil, ugliness and beauty, certainty and mystery, life and death, without trying to reconcile these oppositions by recourse to some preconceived philosophy or a rational system of knowledge. As Keats puts it in a letter of 1817 , negative capability is "when man is capable of being in uncertainties, Mysteries, doubts, without any irritable reaching after fact and reason" (2005, p. 60). For a creative poet to proceed from preconceived goals or ready conclusions is to curtail poetry's real value and function of artistically representing the perpetually fascinating complexity of the world. Poetry should therefore not proceed "impatiently from a knowledge of what is to be arrived at," as Keats emphasizes in another letter (p. 93). Based on this conception of poetry, which refuses to impose its goals and solutions, Keats comes to reject art's overbearing tendencies to moralize, especially as revealed in Wordsworth's habit of forcing on the reader his own philosophical assumptions - what Keats calls as "the wordsworthian or egotistical sublime" (p. 194; see also Sperry, 1994, pp. 60-1; Starr, 1966, p. 60). For our purpose here, negative capability is simply being patient enough to live with tensions, "half knowledge," and uncertainty.

Uncertainty and the ensuing desperation and tension are expressed at least at two levels in "When I Have Fears." At the level of structure, uncertainty is voiced through the modal "may," which is used twice in the first and second stanzas (lines 1,7). At a philosophical level, Keats is expressing uncertainty not only about whether he is going to live or die, but also, implicitly, about what happens after death. Not only is he unsure about his fame continuing after death - in accordance with his wish, his tombstone bears the epitaph: "Here lies one whose name was writ in water" (Keats, 2005, p. xxxii) - but also lacking any redeeming belief in an afterlife. Now, if the poem is implicitly raising the question of how one should respond to the fear of death, the answer involvesa "negative capability," that is, to accept life, short and tragic though it may be, and to accept what life throws your way, even if that was your "death warrant" (2005, p. 413), as Keats would later describe his first blood-spitting. Keats does not try to allay his fears by reconciling contradictory aspects of the human condition such as the desire for life and love with fear of death. He accepts death, which is his fate as it is the fate of humanity at large. Keats ends up standing painfully alone on the shore of the wide world, at the threshold of the unknowable and 
uncertain, but he is not cursing his fate, as Shakespeare, for example, does in sonnet 29 in the related context of complaining about his own presumed worldly failure as a poet:

When, in disgrace with fortune and men's eyes,

I all alone beweep my outcast state,

And trouble deaf heaven with my bootless cries,

And look upon myself and curse my fate. (11.1-4)

Nor is Keats expressing the wish never to write or fall in love again because of his lack of the knowledge of the hour of his death.

In other words, negative capability also means Keats's acceptance of the actual - including suffering and the finality of death - rather than hankering after an impossible romanticized ideal. The real world is harsh, as Keats is well aware. In "Ode to a Nightingale," he speaks of

The weariness, the fever, and the fret

Here, where men sit and hear each other groan

$\cdots$

Where Beauty cannot keep her lustrous eyes,

Or new Love pine at them beyond to-morrow. (11. 23-4, 29-30)

Moreover, in "Ode to Melancholy" Keats is especially conscious of the fleeting nature of joy and the ultimate perishing of beauty:

She dwells with Beauty—Beauty that must die;

And Joy, whose hand is ever at his lips

Bidding adieu; and aching Pleasure nigh,

Turning to poison while the bee-mouth sips. (11. 21-24)

It would be interesting to recall here that in an attempt to free himself from such imperfect world of flux and change, of withering and death, and in search for the ideal and the immortal, Keats initially identifies himself with nature (the nightingale in "Ode to a Nightingale") and art (the urn in "Ode on a Grecian Urn"). Similarly, in "Ode to Psyche" and "Ode to Melancholy," Keats casts himself as a "dreamer" who turns his back on the real world at the beginning of the dream (Stillinger, 1975, pp. 465-6). However, the dream or imaginative flight becomes ultimately a positive experience that increases the poet's appreciation and understanding of the real world rather than cuts him off from it (Stillinger, 1968, p. 3). Richard Macksey (1984), in his study of "To Autumn," speaks of a crucial shift from Keats's earlier search for "an immutable eternity of absolute being" to his acceptance and acknowledgement of "mutability and death" (p.874). Similarly, Stillinger (1975) argues that, if the conflict between the actual and the ideal is at the heart of his final poems and odes, Keats does not reject the actual in favour of the ideal. Rather, he faces up to the actual in a manner that "amounts, in the total view, to affirmation" (p. 466). "Beauty," as Keats states, "is truth, truth beauty,- that is all / Ye know on earth, and all ye need to know" "'Ode on Grecian Urn," 11. 49-50). Perhaps this affirmation of the actual, the here and now, can be demonstrated in a shorter, presumably earlier, poem such as "Bright Star" (1818). In this poem, Keats gives up his yearning for the permanence and non-fading beauty of the star and accepts - in fact celebrates - his human and mortal condition, however imperfect and limited it is. Ironically, Keats comes to realize in the end that the immutability and eternity of the star, which he initially desired, do not only evoke emotional distance and loneliness, but also death.

Noting Keats's acute understanding of such complex human existence, Stillinger (2007) points out to the fact that "There is Keats's clear-headed thinking on some basic problems of human life-his acceptance and even championing of the pleasure pain complexity of mortal existence" (p. 139). Similarly, R. H. Folge (1947) argues that the odes "express an exquisite awareness of the existence of joy and melancholy, pleasure and pain, and art and life. They express a feeling that these are inseparable, although not identical, and they express acceptance of this inseparability of the elements of human experience" (p. 81). Quoting the concluding lines of Keats's "Why Did I Laugh" (1819): "Verse, fame, and beauty are intense indeed, / But death intenser - death is life's high meed" (11. 13-4), Folge argues that insofar as the "Nightingale" is an imaginative reflection of the complexity and intensity of human experience, death may quite reasonably be viewed as its culmination (p. 82). Folge sees that "the value of the imaginative experience depends upon its transience" (p. 83). Extending his observations to the 
"Eve of St Agnes," Folge argues that "Only by being aware of sorrow can the poet devote himself wholehearted to joy, conscious the while that his respite will be brief" (p. 82). Indeed, in the face of such reality, Keats advocates that one should live "the ripest, fullest experience that one is capable of" (Stillinger, 1975, p. 446).

Such an attitude, which is capable of perceiving and accepting the inseparability of the contradictory aspects of the world, such as life and death, can perhaps be best understood in the light of Keats's use of autumnal imagery. "When I Have Fears" opens with an autumnal image of a season of ripeness and completion, which suggests Keats's awareness of death as the inevitable end of an organic process (Elliot, 1979, p. 6). Despite the quality of fulfillment which the concept of ripeness projects, it is also, as Walsh (1981) observers in the context of "Ode to Autumn," "a recognition of transience," and "acceptance of it" (p. 119). The ripeness of Autumn does not only assert the fullness of life; it also suggests its inevitable weathering and death. In Richard Macksey's words, "autumn" is "not about the tumescent plenitude of reality only; it is also about its constituting polar opposite - emptiness" (1984, p. 874). The significance of the image of ripe grains in autumn at the beginning of the poem, however, is that it represents a metaphor of the natural cycle of the seasons, which is the same cycle in human life, as humans pass from youth to adulthood and old age. In a sonnet on the "Human Seasons" (1818), Keats contends that "Four seasons fill the measure of the year." Comparably, "Four seasons are there in the mind of man," who "hath his winter too of pale misfeature, / Or else he would forget his mortal nature" (11. 1-2, 13-4). What this shows is that Keats is not worried about the claims of mortal nature as such, but about an early death curtailing his life, and thus preventing him from completing his natural cycle, from "harvesting" the "fruits" of his mature intellect - qualities that he would possess only when he reaches an advanced stage of development.

Keats's attitude, which acknowledges the mutability of the world without relinquishing the will to live the ripest possible experience - or better, insisting on living to the fullest precisely because everything will eventual wither and die - does indeed show that the tension or conflict between life and death is constitutive of Keats's experience and art (Macksey, 1984, p. 874; Walsh, 1981, p. 55). This can again be made clear through the autumnal imagery. If the autumnal imagery at the beginning of "When I Have Fears" represents the natural pace of life, which a premature death would destroy, it also serves to define and emphasize Keats's poetic potential. To borrow a phrase from Walsh (1981), ripeness is some kind of compensation for the inevitable subsequent process of withering and age as much as it is an assertion of "the validity and vitality of self in the face of death" (p. 125). Just as Keats can devote himself wholeheartedly to joy only by being aware of sorrow, conscious the while that his respite will be brief (Folge, 1947, p. 82), so can the validity and vitality of the self paradoxically be known, measured, and asserted only if juxtaposed with the threat of an imminent death. Keats's literal and metaphorical fear of death thus serves to define, assert and enact his poetic potential against a backdrop of forthcoming absence and "nothingness," in effect showing "death as functionally defining life, absence as giving graspable form to presence," as Macksey (1984) observes in the context of "To Autumn." In this sense, autumnal imagery in Keats displays as coextensive a vital plenitude and an equally productive emptiness (p. 877). Similarly, human passion becomes all the more valuable and sweeter precisely because death shows how short-lived that passion can be.

As we have seen above, the concept of autumnal ripeness in the opening lines of the poem serves to assert and enact Keats's poetic potential, thus projecting some sense of fulfilment. This sense of fulfilment is further augmented by the powerful rhetoric of the poem - an example of the poetic potential Keats asserts and enacts - which also creates in turn its own sense of fulfillment and satisfaction. This is in fact the view held by Andrew Motion (1997) who, interestingly, reads the poem as Keats's response to the threat of poetic failure in the wake of the criticisms made by Leigh Hunt and Shelley of Endymion (p. 225). The sense of fulfillment the poem projects is derived not only from writing a perfect poem that Hunt was incapable of producing, but also, ironically, form the consolations given by a superior art: "Although the first line anticipates the shocking brevity of Keats's existence, it opens the way for an appreciation of 'high-piled books' which reaffirms the durable consolations of art itself" (p. 226). This sense of fulfilment will remain nevertheless ironic: if intimation of imminent death positively draws attention to Keats's poetic potential and makes it appear more palpable, it also increases the awareness, whether on the part of Keats or on ours, of the proportion of the tragedy and devastation of not fulfilling that potential should the hour of an early death strike.

In short, Keats's search for truth lands him in the real imperfect world, a world whose conflicts and contradictions Keats is not only clearly aware of but also prepared, by his concept of negative capability, to accept. Anita Ghosh (2005) describes Keats's ability to understand and accept the complexity of human existence, which involves joy and life as much as it involves suffering and death, as "the gift of tragic acceptance"- a gift more clearly present in him than in any other poet since Shakespeare (p. 265; see also Starr, 1966, p. 60, for a similar observation). As I have pointed out earlier, one aspect of this acceptance is the negation of the "egotistical sublime," which Keats finds and repudiates in Wordsworth. To quote Ghosh again, Keats is "the least solipsistic of poets" in his odes and 
other poems, not only because he is the one most capable of grasping the existence of other "selves totally distinct from his own," but also because he is able to imagine the world continuing to exist after his own demise (p. 265). From a related perspective, Stillinger (2007) also speaks of Keats's "realistic" and "modern" bent of mind, which sets him apart from his romantic peers. Stillinger contends that of all the romantic poets, Keats is the one "most concerned with things of the real world" (p. 140) because of "his skepticism concerning romantic fantasies about the possibility of escaping the consequences of mortality" through "transcendental and pantheistic schemes favoring a higher reality somewhere else" (pp. 139-140). For example, Wordsworth (1798), who develops the concept of "wise passiveness" ("Expostulation and Reply") in similar ways to Keats's negative capability, responds to death, and fear of death, in a completely different "pantheistic" and "transcendental" way, envisioning his death as a way of returning to that mystic union with the immortal spirit permeating the universe:

Until, the breath of this corporeal frame

And even the motion of our human blood

Almost suspended, we are laid asleep

In body, and become a living soul:

While with an eye made quiet by the power

Of harmony, and the deep power of joy,

We see into the life of things. ("Tintern Abbey," 11. 43-9)

If Keats's imaginative engagement with suffering and death differs from that of his romantic peers, it is also different from that of an earlier generation of poets, some of whom Keats admired and modeled himself on. These latter poets usually respond to death by seeking some sort of Christian or secular consolation. For example, they would alleviate their sense of loss with the assurance of an afterlife for the immortal soul, or with worldly fame, the legacy of good deeds, offspring, or human ties of sympathy and love (Miller, 2011, p. 124). However, as Christopher Miller writes, Keats rejects these consolations because they are not "congenial to [his] sensibilities" (p. 133). Stating that "The specter of premature death and unfulfilled potential expressed in [Milton's] 'Lycidas' haunted Keats throughout his brief career" (p. 134), Miller compares between Milton's poem (1638) and Keats's "When I Have Fears." Milton consoles himself about the premature death of his friend, Edward King, by assuring himself that the fame of his friend will transcend the arbitrary limits of cruel "fate" (11. 75-6) and will be eternally preserved in the "perfect witness of all judging Jove" (1. 82). Moreover, in the Christian and classical terms Milton uses in the poem, King is resurrected from his death and lifted to heaven: "So Lycidas sunk low, but mounted high / Through the dear might of Him that walked the waves" (1l. 173-4). Moreover, his soul has become a resident protective spirit, a "Genius of the shore," lending a hand to "To all that wander in that perilous flood" (11. 183, 5). According to Miller, in contrast to Milton's posture, the "agnostic Keats," in his meditation on the possibility of his own premature death, "refuses this religious consolation." For him, "[f]ame is not a heavenly reward." It is "rather a mirage," as Miller points out, though not exactly the kind of illusion "to be seen through and thought away," as Miller goes on to add (pp. 134-5). It is perhaps a mirage in the sense that it continuously evades Keats's eager grasp.

The difference in response to death between Milton and Keats can be further illuminated by comparing Keats's poem with Milton's sonnet "On His Blindess" (1655). Milton's sonnet, which is probably the most potent influence on Keats in this poem, begins with: "When I consider how my light is spent, / Ere half my days in this dark world and wide." In addition to the obvious similarity in the opening lines of the two poems, Keats seems to borrow the imagery and literal words of "this dark world and wide" (1.2) in his construction: "... then on the shore / Of the wide world I stand alone, and think." There is also similarity in the mood and tone of the two poems, as both poets broach the same topic - anxiety about poetic career prospects being thwarted due to early blindness in Milton and early death in Keats. Further, for Milton, it is "death to hide" "that ... talent" (1. 3) - poesy; in Keats it is literal death, or fear thereof, which will prevent the poet from nurturing this talent. Finally, a striking similarity can be observed between Keats's tranquil ending of the poem and his "tragic acceptance" of uncertain fate and Milton's puritan virtue of patience. If Keats's poem is an answer to the question of how to face the prospects of premature death, Milton's poem represents his Christian response to suffering.

In his reflections on contemporary criticism of Keats's odes, James O'Rourke (1998) maintains that Keats's negative capability reflects in some significant sense the celebrated "fort / da," or "gone / there" game of Freud's grandchild, only that Keats's game is a much more radical one that shows his "abilityto play 'gone,' to see how far he can go, without the need to safeguard or recoup the expenditure" (p. xii). O'Rourke's gloss on Keats's negative capability neatly captures Keats's acceptance of suffering, mutability and death, without sublimating 
such life conflicts into some higher principle or seeking some sort of solace in an afterlife. Indeed, if the child's game is one that offers some solace and comfort because it is essentially a game of repetition and mastery (of the painful absence of the mother), Keats's is only a "fort" game, one that foregrounds the preponderance of loss but offers no hope of recovery or solace. Rejecting religious or transcendental assurances of an afterlife, Keats only plays "gone," as O'Rourke puts it. Thus, in the absence of such consolation, the only option left for Keats is the attainment of "a kind of stoic serenity" (Miller, 2011, p. 135), as he stands "on the shore / Of the wide world," lost in thought "Till Love and fame to nothingness do sink."

However, despite his rejection of the solace of an assured, romantic (pantheistic) or traditional (Christian) afterlife, Keats, according to Miller (2011) seems to still harbor some fantasies about the power of art to offer some sort of permanence and immortality. In a scene from his early poem, "I Stood Tip-Toe" (1817), Cynthia and Endymion are given life back and immortalized by a magic spell:

Therefore no lover did of anguish die:

But the soft numbers, in that moment spoken,

Made silken ties, that never may be broken. (11. 236-8)

Miller (2011) cites these lines in support of his argument that "John Keats fantasized about magical remedies to such brokenness," and that he, as the reference to "soft numbers" suggests, believed in "the power of poetry ... as both palliative and curative" (p. 134). However, this power is not acknowledged or celebrated in "When I Have Fears" either as "palliative" or "curative," partly because the original complaint Keats makes here is that he has not yet matured his poetic powers enough to be able to cast that magical spell and save his life and afterlife from obscurity. Moreover, while time runs out, love and fame evade his grasp, simply because "death will sever his connection to the "fair creature of an hour' and to us, to his would-be readers, to posterity," as Calbert writes (2012, p. 171).

Keats's views on the relationship between poetry and (im)mortality invites comparison with those of Shakespeare. As Stallman (1947) argues, "Of the two poets in Keats - the poet who most passionately affirms, and the poet who most passionately denies, time - it is the intensely time-conscious poet who has affinities with Hardy and Shakespeare" (p. 143). "When I Have Fears" is Keats's first and probably greatest Shakespearean sonnet (Gittings, 1970, p. 188), showing the deep influence the great Renaissance poet had on Keats. Structurally, Keats follows closely the Shakespearean sonnet model in which the "when - then" grammatical structure allows the poet to drive a hyperbolic, progressively mounting, sequence of thoughts or feelings towards an exceptionally sad or happy end. Thematically, the poem is concerned with the subjects of poetry, love and death, concerns that are Shakespearean par excellence. In fact, one can hear in Keats's poem echoes from several well-known sonnets by Shakespeare such as sonnet number 12, "When I do count the clock that tells the time;" sonnet number 60, "Like as the waves make towards the pebbled shore;" sonnet number 107, "Not mine own fears, nor the prophetic soul," and sonnet number 64 "When I have seen by Time's fell hand defac'd," which ends significantly on this gloomy note:

This thought is as a death which cannot choose

But weep to have that which it fears to lose.

As I have pointed out earlier, it is this fear of loss of love and fame through death on Keats's part which turns ironically into a metaphorical death that brings an end to the pleasure of love and ambition.

However, there is a great difference between Shakespeare and Keats with regard to their attitudes towards poetry, love, fame, and death. Shakespeare recognizes the enmity of time and death, but the weapon he wields in their face is either love or art. For example, in sonnet 18 it is his poetry which will counter the effects of time on his beloved's beauty and which will ensure her immortality: "Nor shall Death brag thou wander'st in his shade, / When in eternal lines to time thou grow'st" (11. 11-2). However, in sonnet 116 it is the power of love which defeats time and death: "Love ... bears it out to the edge of doom" because "Love's not Time's fool, though rosy lips and cheeks / Within his bending sickle's compass come" (11. 9-14). In contrast, Keats sees poetry and love as time's victims rather than as a means to escape death and achieve immortality. Further, different from Keats's rueful, desolate tone is the boastful, lofty, superior, masculine tone of the epigrams of those sonnets, which displays both Shakespeare's art and his confidence in his art to counter death and confer immortality. For example, the epigram of sonnet 18 boasts: "So long as men can breathe, or eyes can see, / So long lives this, and this gives life to thee." Keats follows Shakespeare thematically and structurally but he, at this stage at least, does not share Shakespeare's vision that poetry, as a kind of art, is a way to transcend the limits of impermanence and human mortality. Of course, Keats several months later in his final odes would follow Shakespeare in positing art (the 
Grecian Urn) and nature (the song of the Nightingale) as capable of immortality, evading time and change (see also Walsh, 1981, p. 132).

Driven by a desire for earliness, Keats, it is recalled, tends to write about the present from the perspective of the future, trying to imagine what it will certainly turn out to be. It is ironic that Keats's critics and commentators have displayed a similar tendency in explaining the early Keats from the perspective of the late Keats. In some sense, this kind of reading is inevitable. Keats's tragically premature death gives more sense to poems expressing a universal human fear, which is as old as humanity itself. Moreover, Keats's poems and the anxieties they contain are justified and confirmed by Keats's actual early death (see also Corcoran, 2009, p. 322). For example, speaking of "Ode to a Nightingale," Walter J. Bate cannot forgo reading the ode from the point of view of Keats's last letter of 30 September 1820 (see Keats, 2005, p. 475), before leaving England for Italy:

One thinks ahead to Keats's last letter before he left England, when he knew that everything was over. The boat from which he wrote to Charles Brown (September 30, 1820) lay off the Isle of Wight - painfully associated by then with his first ambitious effort, his "test Invention:"

"I wish for death every day and night ... and then I wish death away, for death would destroy even those pains which are better than nothing. Land and Sea, weakness and decline, are great separators, but death is the great divorcer for ever." (Bate, 1992, p. 508)

For similar reasons, we cannot afford to overlook how tragically ironic is "Sleep and Poetry" (1816), whether from the perspective of the later and more mature "When I have Fears" or from the perspective of Keats's untimely death itself. As in "When I Have Fears," in "Sleep and Poetry" Keats is worried about his development as a poet. He realizes that he has not come of age as a poet yet, but he can envisage a future in which he will write the kind of poetry that will secure his everlasting fame, and he sets out to meet this challenge (1l. 47-84). However, thinking about his future immediately evokes in his mind the brevity of life and the fears that he may not after all be granted the time to be the great poet he wishes to become in the future (cf Severs, 1959, p. 130). That is why he asks "for ten years, that I may overwhelm / Myself in poesy; so I may do the deed / That my own soul has to itself decreed" (11.96-98). Of course, the tragic irony I mentioned above is the fact that of the ten years Keats begged for, he was granted barely four. In fact, Keats's begging for more time to mature as a poet, and his anxiety about meeting a premature death "Before [his] pen has glean'd [his] teeming brain," are perfectly justified in view of the lengthy time it takes for a literary gift to mature and develop its crucial capacities of observation, imaginative perception, and linguistic and philosophical formulation (Epstein, 1999, p. 45).

There are many other "tragic" ironies involved in Keats's fears about a premature death. He died believing that his great promise had not come to fruition when "in substantial part, it already had" (Epstein, 1999, p. 45). For despite expressing serious fears and anxieties about dying unfilled or about falling into obscurity, only a few months later Keats would write the famous poems and odes that would ensure his everlasting fame. Ironically, fear of death perhaps explains the zeal with which Keats put himself to writing in his annals mirabilis as he composed his best poems, those poems that would place him firmly "among the English Poets" and immortalize his memory. To put it in Freudian parlance, Keats's Eros - the life-instincts - is able to harness his Thanatos - his death anxiety and fears - to the task of creating the best and most astonishingly original poems in English. As Robert Gittings states in John Keats: The Living Year (1968), in this most productive phase of his poetic career, from September 1818 to September 1819, "Keats wrote, with numerous other works, practically every poem that places him among the major poets of the world" (p. 4). With a dizzying variety in style that is difficult to parallel within the same limit of time in the life of other English poets (Bate, 1992, p. 388), Keats completes Hyperion and The Fall of Hyperion, the incomparable odes, and many great poems such as "La Belle Dame sans Merci" and "Sonnet to Sleep." In a comment that seems to justify later critical readings of Keats's letters as a gloss on his poems, F. R. Leavis (1936) points out to the mature synthesis of Keats's philosophy as expressed in his letters and the last masterpieces he wrote, stating that "poet and letter-writer are at last one." These last poems, Leavis adds, are "clearly the expression of a rare maturity; the attitude is the product of tragic experience, met by discipline, in a very uncommonly strong, sincere and sensitive spirit" (p. 400).

In Severn's reported version of Keats's letter of 30 November 1820, the emaciated Keats bitterly asks Dr. Clark a few days before his death: "How long is this posthumous life of mine to last?" (Bate, 1992, p. 693). In a positive sense, "this posthumous life" has continued up to the present and is certain to continue for a long time to come. Today Keats occupies a high place in the pantheon of the great English poets, perhaps on par with Shakespeare and Milton (Epstein, 1999, p. 64). "I think I shall be among the English poets after my death," wrote Keats to his brother and sister-in-law in America in 1818 (2005, p. 199), and his prophecy has finally come true. Unfortunately, Keats did not live long enough to "relish" either his great achievement or the fame it 
won him. Moreover, despite believing that poetry is victim of death and fear of it, it is ironically through his surviving poetry that Keats has overcome his death and become immortal.

One last irony to mention here by way of concluding this article is the fact that though Keats feared that an early death would not give him the opportunity to be acknowledged and famous, it is in a sense precisely his death premature and tragic, as it is - which has contributed to his posthumous fame and afterlife and turned him into a legend. Considering our fascination with how remarkable, unique, rich, mature, and extensive his achievement is, despite his brief career of barely four years, we keep wondering curiously about how much he would have further excelled himself as well as his Romantic peers had he been given a longer life, all the while feeling deeply saddened by the early departure of such a genius (cf Elliot, 1921). "Some of the poignancy and punch of this particular poem, for me,"writes Calbert with reference to "When I Have Fears," "comes from knowing, and deeply admiring, Keats's oeuvre" $(2012,171)$. Indeed, Keats's brief chance at life, love, and poetry has rendered his achievement all the more awe-inspiring and his untimely death all the more tragic. It is these facts about Keats that will keep his memory alive in the minds of present and future generations.

\section{References}

Bate, W. J. (1992). John Keats. London: The Hogarth Press. (Original work published 1963).

Brett, R. L., \& Jones, A. R. (Eds.). (2005). William Wordsworth and Samuel Taylor Coleridge: Lyrical Ballads (2nd ed.). London: Routledge. (Original work published 1968).

Burrow, C. (Ed.) (2002). William Shakespeare: The Complete Sonnets and Poems. Oxford: Oxford University Press.

Bush, D. (1963). Mythology and the Romantic Tradition in English Poetry. New York: The Norton Library. (Original work published 1937).

Calbert, C. (2012). On "When I Have Fears." Poetry East, 74/75, 171.

Carey, J. (Ed.). (1997). John Milton: The Complete Shorter Poems (2nd ed.). Harlow, England: Pearson. (Original work published 1968).

Chander, M. S. (2012). A Review of In the Presence of Absence by Mahmoud Darwish. The Literary Review, $55(2), 215$.

Coote, S. (1995). John Keats: A Life. London: Hodder and Stoughton.

Corcoran, B. (2009). Keats's Death: Towards a Posthumous Poetics. Studies in Romanticism, 48(2), 321-348. Retrieved from http://www.jstor.org/stable/25602195

Cross, S. (2011). Keats and the Temporal Imagination. Raritan: A Quarterly Review, 30(4), 117-129. Retrieved fromhttp://www ebscohost.com

Cunningham, A. (Ed.). (1855). The Complete Works of Robert Burns. Retrieved from http://www.gutenberg.org/files/18500/18500-h/18500-h.htm

Elliot, G. R. (1921). The Real Tragedy of Keats (A Post-Centenary View). PMLA, 36(3), 315-331. Retrieved from http://www.jstor.org/stable/457195

Elliot, N. (1979). Keats's When I Have Fears. ARIEL: A Review of International English Literature, 10(1), 3-10.

Epstein, J. (1999). The Medical Keats. The Hudson Review, 52(1), 44-64. http://dx.doi.org/10.2307/3852571

Fogle, R. H. (1947). A Note on Keats's 'Ode to a Nightingale.' Modern Language Quarterly, 8(1), 81-84. http://dx.doi.org/10.1215/00267929-8-1-81

Ghosh, A. (2005). Imagery in John Keats's Famous Odes and Other Poems: A Critical Study. In A. Nagar \& M. N. Prasad (Eds.). Recritiquing John Keats (pp. 259-268). New Delhi: Sarup \& Sons.

Gittings, R. (1968). John Keats: The Living Year. London: Heinemann. (Original work published 1954).

Gittings, R. (1970). John Keats. London: Heinemann. (Original work published 1968).

Goldberg, M. A. (1957). The "Fears" of John Keats. Modern Language Quarterly, 18(2), 125-131. http://dx.doi.org/10.1215/00267929-18-2-125

Keats, J. (1982). John Keats: Complete Poems. J. Stillinger (Ed.). Cambridge, MA: Belknap Press. (Original work published 1978).

Keats, J. (2005). Selected Letters of John Keats. G. F. Scott (Ed.) (2nd ed.). Cambridge, MA: Harvard University Press. (Original work published 1958). 
Leavis, F. R. (1936). Revaluations (IX): Keats. Scrutiny: A Quarterly Review, 4(4), 376-400.

Macksey, R (1984). Keats and the Poetics of Extremity. MLN, 99(4), 845-884. Retrieved from http://www.jstor.org/stable/2905506

Miller, R. C. (2011). Pastures New and Old: The Romantic Afterlife of Pastoral Elegy. In C. Mahoney (Ed.), A Companion to Romantic Poetry (pp. 123-139). Oxford: Blackwell. http://dx.doi.org/10.1002/9781444390650.ch8

Motion, A. (1997). Keats. London: Faber and Faber.

O’Rourke, J. (1998). Keats's Odes and Contemporary Criticism. Gainesville: UniversityPress of Florida.

Roe, N. (2012). John Keats: A New Life. New Haven and London: Yale University Press.

Schor, E. (2011). Stirring shades: The Romantic Ode and Its Afterlives. In C. Mahoney (Ed.), A Companion to Romantic Poetry (pp. 107-122). Oxford: Blackwell. http://dx.doi.org/10.1002/9781444390650.ch7

Severs, J. B. (1959). Keats's 'Mansion of Many Apartments,' Sleep and Poetry, and Tintern Abbey. Modern Language Quartely, 20(2), 128-132. http://dx.doi.org/10.1215/00182702-20-2-128

Sperry, S. M. (1994). Keats the Poet. Princeton: Princeton University Press.

Stallman, R. W. (1947). Keats the Apollinian: The Time-and-Space Logic of his Poems as Paintings. University of Toronto Quarterly, 16(2), 143-156. http://dx.doi.org/10.3138/utq.16.2.143

Starr, N. C. (1966). Negative Capability in Keats's Diction. Keats-Shelley Journal, 15, 59-68. Retrieved from http://www.jstor.org/stable/30209856

Stillinger, J. (1975). The Hoodwinking of Madeline: Skepticism in 'The Even of St. Agnes.' In M. H. Abrams (Ed.), English Romantic Poets: Modern Essays in Criticism (2nd ed., pp. 448-469). London: Oxford University Press.

Stillinger, J. (2007). Keats and Me. Wordsworth Circle, 38(3), 139-143.

Stillinger, J. (Ed.). (1968). Twentieth Century Interpretations of Keats's Odes: A Collection of Critical Essays. London: Prentice-Hall.

Tyson, L. (2006). Critical Theory Today: A User-Friendly Guide (2nd ed.). Routledge: London and New York.

Walsh, W. (1981). Introduction to Keats. London and New York: Metheun.

Williams, M. (1958). The Fear of Death. Journal of Analytical Psychology, 3(2), 157-165. http://dx.doi.org/10.1111/j.1465-5922.1958.00157.x

Williams, M. (1962). The Fear of Death. Journal of Analytical Psychology, 7(1), 29-40. http://dx.doi.org/10.1111/j.1465-5922.1962.00029.x

\section{Copyrights}

Copyright for this article is retained by the author(s), with first publication rights granted to the journal.

This is an open-access article distributed under the terms and conditions of the Creative Commons Attribution license (http://creativecommons.org/licenses/by/3.0/). 